\title{
SPLENIC PROTECTIVE EFFECT OF WHITE TURMERIC EXTRACT AGAINST COPPER TOXICITY IN MALE WISTAR RATS
}

\author{
LINDA CHIUMAN*, FAHRUL AZMI TANJUNG, DJAMIN
}

Department of Faculty of Medicine, Universitas Prima Indonesia, North Sumatera, Indonesia. Email: lindachiuman@unprimdn.ac.id Received: 19 August 2021, Revised and Accepted: 16 March 2021

\begin{abstract}
Objective: This study was aimed to investigate the protective effect of white turmeric against copper splenic toxicity in male Wistar rats.

Methods: This study used 30 rats divided into six groups: Negative groups, positive groups, Ethanol Extract of White Turmeric I-III. After 14 days, all rats were sacrificed by chloroform inhalation, and the spleen was excised and process to histopathology preparation and evaluation.

Results: The result of this study showed that white turmeric acutely protected spleen from the impact of copper by reducing congestion/vasodilatation of the blood vessel $(\mathrm{p}=0.002)$, neutrophil infiltration $(\mathrm{p}<0.05)$, and lymphoid necrosis $(\mathrm{p}<0.05)$. Nevertheless, white turmeric extract may induce chronic inflammation by increasing the number of macrophage cells $(\mathrm{p}=0.003)$.
\end{abstract}

Conclusion: Overall, it can be concluded that the white turmeric extracts acutely protect spleen from the impact of copper.

Keywords: Copper, Ethanol, Spleen, White turmeric.

(C) 2021 The Authors. Published by Innovare Academic Sciences Pvt Ltd. This is an open access article under the CC BY license (http://creativecommons.org/ licenses/by/4.0/) DOI: http://dx.doi.org/10.22159/ajpcr.2021v14i5.40789. Journal homepage: https://innovareacademics.in/journals/index.php/ajpcr

\section{INTRODUCTION}

Copper is one of the pollutions. Ironically, the human body required a lower number of coppers for maintaining homeostasis, but the higher intake of copper can cause various organ damages, impaired regulation of lipid metabolism, impaired antimicrobial defense, neuronal activity, and resistance chemotherapies. Furthermore, the high levels of copper in the body can also stimulate reactive oxygen species (ROS) production and modify low-density lipoprotein to promote atherogenesis by enhancing the transformation of macrophages and developing vasoconstrictor and prothrombotic characteristics [1].

Some studies have been performed to investigate the environment pollution in some countries. One of these studies was reported that Some Rainwater Tanks in Adelaide Region, Australia, have been polluted by several heavy metals. Most of the pollution was lead. Other heavy metals such as zinc, cadmium, and copper were detected in the fewer samples, especially in the Adelaide Hills and Foothills [2].

The higher number of the copper may be eliminated by Reticular Endothelial System. One of these systems, Spleen, is located in the left upper quadrant of the abdomen. This organ functions included filtration of blood, production of white blood cells, and reserving of blood. The overload copper may cause dysfunction of the spleen, reducing red blood cells, white blood cells, and platelet in the circulation. Therefore, the immunity will decrease and vulnerable to be an infection [3].

Some studies have been performed to look for natural resources that can be used to protect the human body against the impact of copper pollution. One of the natural resources is white turmeric rhizome (Curcuma zedoaria). It contains curcumin with some pharmacological properties, including anti-inflammatory, antioxidant, and anti-cancer activity $[4,5]$ Due to the presence of antioxidant activity from the white turmeric, it potentially protects various organs against copper. Some studies have been performed to look for white turmeric's protective effect against kidney and systemic protection (indicated by hematologic study) [6-8]. However, none of the studies investigates the protection effect of white turmeric against copper in spleen tissue. For these reasons, this study was designed to investigate the splenic protective effect of white turmeric rhizome (C. zedoaria) against cooper using male Wistar rats as the animal trial.

\section{METHODS}

This was an experimental study with post only group control design. This study was performed on July 2020-October 2020 at Pharmacology Laboratory, Universitas Prima Indonesia. This study's procedure has been approved by the Health Research Ethics Committee from Universitas Prima Indonesia with registration no. 052/KEPK/ UNPRI/V/2020.

\section{Materials}

The material used in this study included white turmeric, copper sulfate pentahydrate, $96 \%$ ethanol, distilled water, sodium carboxymethylcellulose, alcohol, buffer phosphate, xylol, paraffin, and HE Staining.

\section{Identification and preparation of white turmeric}

The White turmeric ( $C$. zedoaria) was obtained from UPT Materia Medica Batu, Jawa Timur. The white turmeric was cleaned, dried, and meshed to get the simplicia powder. Moreover, the simplicia powder was soaked into $96 \%$ ethanol as the solvent, every $24 \mathrm{~h}$ it was filtered, and the filtrate was collected, and the residue was soaked again as before, these processes were repeated twice. Finally, the filtrate was evaporated by rotary evaporator at $50^{\circ} \mathrm{C}$ until the filtrate becomes concentrated $[8,9]$.

\section{Formulation of oral suspension}

The oral suspension was made of sodium carboxymethylcellulose. Amount of $0.5 \mathrm{~g}$ sodium carboxymethylcellulose was suspended into $30 \mathrm{ml}$ hot distilled water in the mortar for $15 \mathrm{~min}$ until it formed a clear suspension. Moreover, this suspension was grounded until it becomes homogeneous. After that, it was dissolved until $100 \mathrm{ml}$ by distilled water.

The obtained suspension was used as vehiculum for extract and copper sulfate pentahydrate. Amount of $45 \mathrm{mg}, 67.5 \mathrm{mg}$, and $90 \mathrm{mg}$ of 
extract was mixed into $5 \mathrm{ml}$ of $0.5 \%$ sodium carboxymethyl cellulose suspension to form extract suspension dosage $10 \mathrm{mg} / 200 \mathrm{~g} \mathrm{BW}$, $20 \mathrm{mg} / 200 \mathrm{~g} \mathrm{BW}$, and $40 \mathrm{mg} / 200 \mathrm{~g} \mathrm{BW}$, respectively. Last, the amount of $0.36 \mathrm{mg}$ copper sulfate pentahydrate was mixed into $5 \mathrm{ml}$ of $0.5 \%$ sodium carboxymethylcellulose to form copper sulfate suspension [10].

\section{Intervention}

This study was used 30 rats which were divided into six groups. The intervention was shown as the following.

a. Normal: Rats did not receive any interventions.

b. Negative: Rats received $1 \mathrm{ml}$ of copper sulfate pentahydrate by intragastric oral tube once a days in the $12^{\text {th }}, 13^{\text {th }}$, and $14^{\text {th }}$.

c. Positive: Rats received $1 \mathrm{ml}$ of extract suspension dosage $10 \mathrm{mg} / 200$ g BW by intragastric oral tube once a day every day.

d. Ethanol extract of white turmeric-I: Rats received $1 \mathrm{ml}$ of extract suspension dosage $10 \mathrm{mg} / 200 \mathrm{~g} \mathrm{BW}$ by intragastric oral tube once a day every day for 14 days and $1 \mathrm{ml}$ of copper sulfate pentahydrate by intragastric oral tube once a days in the $12^{\text {th }}, 13^{\text {th }}$, and $14^{\text {th }}$.

e. Ethanol extract of white turmeric-II: Rats received $1 \mathrm{ml}$ of extract suspension dosage $20 \mathrm{mg} / 200 \mathrm{~g}$ BW by intragastric oral tube once a day every day for 14 days and $1 \mathrm{ml}$ of copper sulfate pentahydrate by intragastric oral tube once a days in the $12^{\text {th }}, 13^{\text {th }}$, and $14^{\text {th }}$.

f. Ethanol extract of white turmeric-III: Rats received $1 \mathrm{ml}$ of extract suspension dosage $40 \mathrm{mg} / 200 \mathrm{~g}$ BW by intragastric oral tube once a day every day for 14 days and $1 \mathrm{ml}$ of copper sulfate pentahydrate by intragastric oral tube once a day in the $12^{\text {th }}, 13^{\text {th }}$, and $14^{\text {th }}$

All rats can freely access food and drink. After 14 days, all rats were sacrificed to obtain the spleen for histology evaluation.

\section{Sacrificed of rats}

All rats were sacrificed by inhalation of chloroform in the close room. After that, the rat abdomen was incised horizontally. The spleen was collected from the chest cavity and washed into the normal saline. The washed spleen was soaked into $10 \%$ formalin buffer saline, and it was reserved until the tissue processing $[9,10]$.

\section{Tissue processing}

The spleen was sliced to thickness 4-6 mm. After that, it was dehydrated with several alcohol concentrations (70\%, 80\%, 90\%, and 95\%) for $24 \mathrm{~h}$ and followed by $100 \%$ alcohol for an hour for 3 times. After that, it was purified by xylol for an hour for 3 times. Moreover, the tissue was infiltrated into the paraffin, and it was incised to thickness 4-5 microns. Finally, the incision was attached to the slide and stained by hematoxylin-eosin (HE) staining $[9,10]$

\section{Evaluation of spleen tissue}

The spleen tissue was observed under the light microscope at the $\times 100$ and $\times 400$ magnified. Four parameters which were used to evaluated spleen tissue included congestion or vasodilation of blood vessels, neutrophile infiltration. The scoring system was used to evaluate that the spleen histology is shown in Table $1[11,12]$.

Table 1: Scoring system of lung tissue

\begin{tabular}{|c|c|}
\hline Parameter & Score \\
\hline Congestion or vasodilation & a. Yes \\
\hline of blood vessel & b. No \\
\hline \multirow[t]{2}{*}{ Neutrophil infiltration } & a. Yes \\
\hline & b. No \\
\hline Lymphoid & $0:$ None of necrotic foci \\
\hline \multirow[t]{5}{*}{ necrosis } & $1+:<5 \%$ necrotic foci per $200 \mathrm{HPF}$ (mini) \\
\hline & $2+: 5-25$ necrotic foci per $200 \mathrm{HPF}$ (mild) \\
\hline & $3+: 25-50$ necrotic foci per \\
\hline & 200 HPF (moderate) \\
\hline & $4+:>50 \%$ necrotic foci per $200 \mathrm{HPF}$ \\
\hline $\begin{array}{l}\text { Number of macrophages } \\
\text { in } 20 \mathrm{HPR}\end{array}$ & $\begin{array}{l}\text { It was shown as the number of } \\
\text { macrophages cells in } 20 \mathrm{HPF}\end{array}$ \\
\hline
\end{tabular}

Data analysis

Each of the parameters was analyzed descriptively. Moreover, these data were analyzed by Chi-square for congestion/vasodilatation of blood vessels and neutrophile infiltration. Meanwhile, lymphoid necrosis and macrophages were analyzed by either one-way ANOVA or Kruskal-Wallis, depending on the normality of data. The Shapiro-Wilk analyzed the normality of that.

\section{RESULTS}

The white turmeric extract significantly affects the severity of lymphoid necrosis, the number of macrophage cells, the presence of congestion/ vasodilatation of blood vessels, and neutrophile infiltration. These tables showed these data.

Congestion or vasodilatation in this study was express as the number and percentage of the rat. Meanwhile, the analysis was used to look for the difference among all groups of intervention. Table 2 below showed the result of the analysis.

There are significantly different intervention groups due to $\mathrm{p}<0.05$ $(p=0.002)$. It is shown in Table 2. The normal group showed the highest number of rats that had congestion or vasodilatation of the blood vessel. The negative groups that only received white turmeric did not show any congestion or vasodilation of the blood vessel. Moreover, allwhite turmeric groups (I-III) showed reducing the number of rats with the blood vessel's congestion/vasodilation.

Another parameter, neutrophile infiltration, was shown and analyzed in the same way as the congestion/vasodilation of blood vessels. Table 3 below showed the result of this analysis.

The table obviously showed above that each group showed significant differences $(p<0.05)$. Interestingly, the positive group did not show any

Table 2: Number of rats suffer from congestion or vasodilatation of a blood vessel in spleen tissue

\begin{tabular}{|c|c|c|c|c|}
\hline \multirow[t]{2}{*}{ Group } & \multicolumn{2}{|c|}{$\begin{array}{l}\text { Congestion/ } \\
\text { vasodilation blood } \\
\text { vessel }\end{array}$} & \multirow[t]{2}{*}{ Total } & \multirow[t]{2}{*}{ p-value } \\
\hline & Yes & No & & \\
\hline Normal & $4(16.7)$ & $0(0.0)$ & $4(16.7)$ & 0.002 \\
\hline Negative & $0(0)$ & $4(16.7)$ & $4(16.7)$ & \\
\hline Positive & $2(8.3)$ & $2(8.3)$ & $4(16.7)$ & \\
\hline $\begin{array}{l}\text { Ethanol extract of } \\
\text { white turmeric-I }\end{array}$ & $2(8.3)$ & $2(8.3)$ & 4 (16.7) & \\
\hline $\begin{array}{l}\text { Ethanol extract of } \\
\text { white turmeric-II }\end{array}$ & $0(0)$ & $4(16.7)$ & 4 (16.7) & \\
\hline $\begin{array}{l}\text { Ethanol extract of } \\
\text { white turmeric-III }\end{array}$ & $0(0)$ & 4 (16.7) & 4 (16.7) & \\
\hline Total & $8(33.3)$ & $16(66.7)$ & $24(100.0)$ & \\
\hline
\end{tabular}

p-value was obtained by Chi-square test

Table 3: Number of rats suffer from neutrophil infiltration in spleen tissue

\begin{tabular}{lllll}
\hline \multirow{2}{*}{ Group } & \multicolumn{2}{l}{ Neutrophil infiltration } & \multirow{2}{*}{ Total } & p-value \\
\cline { 2 - 3 } & \multicolumn{2}{l}{ Yes } & No & \\
\hline Normal & $4(16.7)$ & $0(0.0)$ & $4(16.7)$ & $<0.05$ \\
Negative & $4(16.7)$ & $0(0.0)$ & $4(16.7)$ & \\
$\begin{array}{l}\text { Positive } \\
\text { Ethanol extract of }\end{array}$ & $0(0)$ & $4(16.7)$ & $4(16.7)$ & \\
$\begin{array}{lllll}\text { white turmeric-I } \\
\text { Ethanol extract of }\end{array}$ & $3(14.3)$ & $4(16.7)$ & $4(16.7)$ & \\
white turmeric-II & & & & \\
Ethanol extract of & $4(16.7)$ & $0(0.0)$ & $4(16.7)$ & \\
white turmeric-III & & & & \\
Total & $15(62.5)$ & $9(37.5)$ & $24(100.0)$ & \\
\hline
\end{tabular}


neutrophile infiltrations, while the normal and negative groups showed the opposite. Furthermore, all-white turmeric groups (I-III) showed reduced rats with neutrophil infiltration, depending on the extract's dosage. Fig. 1 below shown the microscopic view of neutrophile infiltration.

This study was also analyzed the severity of lymphoid necrosis by the Kruskal-Wallis test and followed by the Mann-Whitney test. Table 4 below showed the result of this analysis.

Table 4 above showed that each group had significant differences in lymphoid necrosis score due to $\mathrm{p}<0.05(\mathrm{p}=0.002)$. The normal and positive group did not show any degrees of lymphoid necrosis. However, the highest score of lymphoid necrosis was shown by the negative group. Nevertheless, the median score of lymphoid necrosis showed a decrease followed by the group's increase, but this reduction was not significant compared to the negative group, instead of the normal or positive group.

Finally, this study was also analyzed the number of macrophages cells in the spleen tissue in the same way used to analyze the severity of lymphoid necrosis. Table 5 below showed the result of the analysis.

According to Table 5 above, the negative group has the highest number and narrowest range of macrophage cells. As the opposite, the normal, positive, and white turmeric-I group were the lowest number of macrophage cells. Meanwhile, the increasing white turmeric dosage was followed by the increasing number of macrophage cells. However, the highest dosage of white turmeric has a significant difference in the number of macrophage cells against white turmeric's lowest dosage. Fig. 2 below showed microscopic view of the macrophages cell in medium - ( $\times 100$ magnified $)$ and high-power field ( $\times 400$ magnified $)$.

Table 4: Analysis of lymphoid necrosis in spleen of the intervention groups

\begin{tabular}{lll}
\hline Group & $\begin{array}{l}\text { Lymphoid necrosis } \\
\text { (Median [Min-Max]) }\end{array}$ & p-value* \\
\hline Normal & $0.00[0.00-0.00]^{\mathrm{a}}$ & 0.002 \\
Negative & $2.00[1.00-3.00]^{\mathrm{b}}$ & \\
Positive & $0.00[0.00-0.00]^{\mathrm{a}}$ & \\
Ethanol extract of white & $1.50[1.00-2.00]^{\mathrm{b}}$ & \\
turmeric-I & $1.50[1.00-2.00]^{\mathrm{b}}$ & \\
$\begin{array}{l}\text { Ethanol extract of white } \\
\text { turmeric-II }\end{array}$ & & \\
$\begin{array}{l}\text { Ethanol extract of white } \\
\text { turmeric-III }\end{array}$ & $1.00[1.00-1.00]^{\mathrm{b}}$ & \\
\hline
\end{tabular}

*The $P$ value was obtained from Kruskal-Wallis Test, ${ }^{\text {a }}$ There is significant differences against the negative group according to Mann-Whitney Test, ${ }^{\mathrm{b}}$ There is significant difference against both normal and positive group according to Mann-Whitney test

Table 5: Analysis of number of macrophage cells in spleen of intervention groups

\begin{tabular}{lll}
\hline Group & $\begin{array}{l}\text { Number of } \\
\text { macrophage cells } \\
\text { (median [IQR]) }\end{array}$ & p-value* \\
\hline Normal & $2.50[2.00-3.00]^{\mathrm{a}}$ & 0.003 \\
Negative & $5.00[5.00-5.00]^{\mathrm{b}}$ & \\
Positive & $2.50[2.00-3.00]^{\mathrm{a}}$ & \\
Ethanol extract of white turmeric-I & $2.50[2.00-3.00]^{\mathrm{a}}$ & \\
Ethanol extract of white turmeric-II & $4.50[3.00-5.00]^{\mathrm{a}}$ & \\
Ethanol extract of white turmeric-III & $5.00[4.00-5.00]^{\mathrm{bc}}$ & \\
\hline
\end{tabular}

*The $P$-value was obtained from Kruskal-Wallis Test, ${ }^{a}$ There is significant differences against the negative group according to Mann-Whitney Test, ${ }^{\mathrm{b}}$ There is significant difference against both normal and positive group according to Mann-Whitney test, ${ }^{c}$ There is significant difference against the white turmeric-I according to Mann-Whitney test

\section{DISCUSSION}

It becomes obvious that the ethanol extract of white turmeric may protect spleen from the impact of copper. The increase of ethanol extract of white turmeric gave better protection of spleen against copper. It was shown by the improvement of acute inflammatory changes in the spleen such as congestion/vasodilatation of the blood vessel, neutrophile infiltration, and lymphoid necrosis. However, prolonged consumption of white turmeric showed increasing the number of macrophage cells in the spleen tissue.

Copper is an essential micronutrient and cofactor for various enzymes. The regulation of this nutrient is closely regulated. The excess level of copper in the body can induce oxidative stress which leads to an inflammatory response $[13,14]$. White turmeric contains more than 20 types of phytochemicals can be found in the white turmeric, include furanodiene, furanodienone, zederone, curzerenone, curzeone, germacrone, 13-hydroxygermacrone, dehydrocurdione, curcumenone, zedoaronediol, 13-hydroxycurzerenone, 1oxocurzerenone, curcolone, procurcumenol, ermanin, curcumin, the mixture of stigmast-4-en-3,6 dione, and stigmata-4,22-dien-3,6. More than these phytochemicals are responsible for white turmeric's pharmacology properties such as antioxidant and anti-inflammatory effect. These phytochemicals reduce the toxicity of copper by donor proton (hydrogen ion) to neutralize the free radical, and it reduces the formation of ROS $[15,16]$.

Acute inflammation is characterized by the accumulation of fluid and plasma at the affected site (due to vasodilation), intravascular activation of platelets, and polymorph nuclear neutrophils as inflammatory cells. Meanwhile, chronic inflammation is the presence of chronic inflammatory cells such as lymphocyte, plasma cells, and macrophages, granulation tissue formation, and in a specific situation as granulomatous inflammation. When the causative agent successfully eliminated by the inflammation, the inflamed area was resolution instead of necrosis [17]. This study showed that increasing white turmeric extract dosage improved the acute inflammation, but it induced chronic inflammation by the increasing number of macrophage cells [17].

The result of this study was supported by the study performed by Fiska et al. They reported that white turmeric protected the kidney from the impact of copper by reducing the level of ureum and creatinine serum and improving the histology changes in the kidney. Another study performed by Chiuman et al. also showed that prolonged consumption of white turmeric increased granulocyte level based on a hematologic study among copper-induced rats. Meanwhile, Ongko et al. reported that the white turmeric has a potential genotoxic property [6-9].

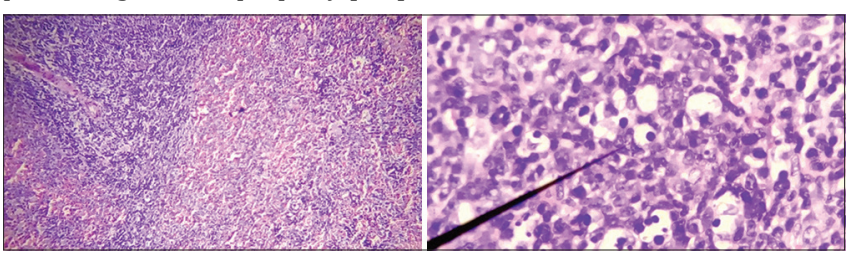

Fig. 1: Neutrophile infiltration in White Pulp at $\times 100$ magnified (left) and $\times 400$ magnified (right). The black pointer pointed the neutrophile cell. Staining: HE Staining

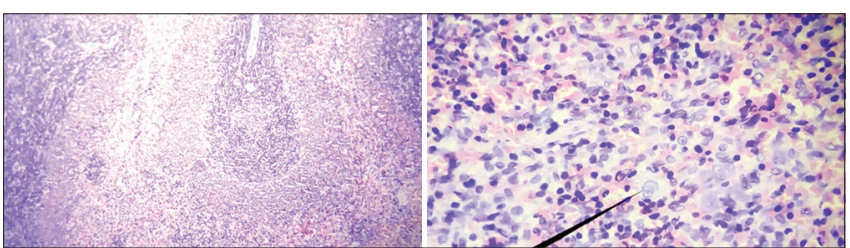

Fig. 2: Macrophage cell in two different magnified: $\times 100$ (Left) and $\times 400$ (Right). The black pointer pointed the macrophage cell. Stain: HE Staining 


\section{CONCLUSION}

It can be concluded that white turmeric may acutely protect spleen from the impact of copper. The increasing of white turmeric dosage shows better splenic protection against copper. However, the higher and prolonged consumption of white turmeric may induce chronic inflammation

\section{ACKNOWLEDGMENTS}

The author(s) disclosed receipts of the financial support for the research and/or publication of this article.

\section{AUTHORS' CONTRIBUTION}

Linda Chiuman - Writing manuscript, evaluation of microscopic view, and final approval. Fahrul Azmi Tanjung - Data collection, data analysis, interpretation of data, and final approval. Djamin - Writing manuscript, Concept and designing the study, data collection, and final approval.

\section{CONFLICT OF INTEREST}

The authors declare that there was no conflict of interest.

\section{AUTHORS FUNDING}

This study was fully funded by the Ministry of Research, Technology, and Higher Education by Funding Contact No. 282/LLI/PG/2020.

\section{REFERENCES}

1. Gaetke LM, Chow-Johnson HS, Chow CK. Copper: Toxicological relevance and mechanisms. Arch Toxicol 2014;88:1929-38.

2. Chubaka CE, Whiley H, Edwards JW, Ross KE. Lead, zinc, copper, and cadmium content of water from South Australian rainwater tanks. Int J Environ Res Public Health 2018;15:1551.

3. De Porto AP, Lammers AJ, Bennink RJ, ten Berge IJ, Speelman P, Hoekstra JB. Assessment of splenic function. Eur J Clin Microbiol Infect Dis 2010;29:1465-73.
4. Rivera-Espinoza Y, Muriel P. Pharmacological actions of curcumin in liver diseases or damage. Liver Int 2009;29:1457-66.

5. Lakshmi S, Padmaja G, Remani P. Antitumour effects of isocurcumenol isolated from Curcuma zedoaria rhizomes on human and murine cancer cells. Int J Med Chem 2011;2011:253962.

6. Wardhani FM, Chiuman L, Novalinda Ginting C, Ginting SF, Nasution AN. Efek Ekstrak Kunyit Putih (Curcuma zedoaria) Sebagai Nefroprotektor Pada Tikus Putih Jantan Galur Wistar yang Diinduksi Tembaga. J Indones Med Assoc 2019;69:258-66.

7. Wardhani FM, Chiuman L, Novalinda Ginting C, Ginting SF. Role of cystatin-C as serum biomarkers in predicting glomerular functionassociated with copper-induced acute kidney injury. Maj Kedokt Bandung 2020;52:16-21.

8. Chiuman L. Protective effect of Curcuma zedoaria against copper in rats' white blood cell. Am Sci Res J Eng Technol Sci 2019;59:142-8.

9. Ongko NX, Chiuman L, Ginting CN. Effect of White turmeric rhizome extract (Curcuma zedoaria) on testis histology of male wistar rat. Am Sci Res J Eng Technol Sci 2019;55:69-74.

10. Mutia MS, Chiuman L. Hepatoprotective effect of Citrus sinensis (L.) osbeck ethanol extract in paracetamol-induced rats. Maj Kedokt Bandung 2019;51:189-93.

11. Akcılar R, Akcılar A, Şimşek H, Koçak FE, Koçak C, Yümün G, et al. Hyperbaric oxygen treatment ameliorates lung injury in paraquat intoxicated rats. Int J Clin Exp Pathol 2015;8:13034-42.

12. Aldahmash BA, El-Nagar DM. Antioxidant effects of captopril against lead acetate-induced hepatic and splenic tissue toxicity in swiss albino mice. Saudi J Biol Sci 2016;23:667-73.

13. Pereira TC, Campos MM, Bogo MR. Copper toxicology, oxidative stress and inflammation using zebrafish as experimental model. J Appl Toxicol 2016;36:876-85.

14. Lai X, Zhao H, Zhang Y, Guo K, Xu Y, Chen S, et al. Intranasal delivery of copper oxide nanoparticles induces pulmonary toxicity and fibrosis in C57BL/6 mice. Sci Rep 2018;8:4499.

15. Rajkumari S, Sanatombi K. Nutritional value, phytochemical composition, and biological activities of edible Curcuma species: A review. Int J Food Prop 2017;20:2668-87.

16. Dosoky NS, Setzer WN. Chemical composition and biological activities of essential oils of Curcuma species. Nutrients 2018;10:1196.

17. Mohan H. Textbook of Pathology. $6^{\text {th }}$ ed. New Delhi: Jaypee Publisher; 2010. p. 592-648. 